\title{
Occurrence and phylogenetic analysis of 'Candidatus Mycoplasma haemominutum' in wild felines from Paraná, Brazil
}

\section{Ocorrência e análise filogenética de 'Candidatus Mycoplasma haemominutum' em felinos selvagens no Paraná, Brasil}

\author{
Claudia Mello Ribeiro' ${ }^{1 *}$; Aldair Calistro de $\mathrm{Matos}^{2}$; Virgínia Bodelão Richini- \\ Pereira $^{3}$; Simone Baldini Lucheis ${ }^{4}$; Felippe Azzolinii'; Juliane Patrícia Sipp ${ }^{5}$; \\ Patrícia Paiva Lima ${ }^{1}$; Satie Katagiri ${ }^{6}$; Odilon Vidotto ${ }^{7}$
}

\begin{abstract}
Hemoplasma infections are emerging and wild fauna can represent an important reservoir of these pathogens. However, there are very few epidemiological studies about the occurrence of hemoplasmas in wild cats around the world. The purpose of this study is twofold: (1) evaluate the occurrence and phylogeny of hemoplasmas in captive wild felines at a zoo in the state of Paraná, Brazil, and (2) verify the correlation between subpopulations of these bacteria and the hematological and biochemical parameters of the animals. PCR was used to detect hemoplasmas in the blood of three cougars (Puma concolor), a jaguar (Panthera onca), a tiger (Panthera tigris) and a lion (Panthera leo), followed by sequencing and phylogenetic analysis. The cougars and jaguar were found to be hemoplasma-positive by PCR. The phylogenetic analysis of the $16 \mathrm{~S}$ rRNA gene sequences enabled the identification of genotypes of 'Candidatus Mycoplasma haemominutum' circulating in this zoo. The identified sequences were closely related to hemoplasma sequences originating from domestic cats and other wild cats, but the infected cougars and jaguar were healthy and showed no hematological or biochemical changes. It was concluded that $P$. concolor and $P$. onca are exposed to 'Candidatus Mycoplasma haemominutum' in Paraná, but further research is suggested to assess the resistance of wild cats to different hemoplasma subpopulations.
\end{abstract}

Key words: Hemoplasmas. Molecular characterization. Panthera onca. PCR. Puma concolor.

\section{Resumo}

Infecções por hemoplasmas são emergentes e os animais selvagens podem representar um importante reservatório desses patógenos. Entretanto, são escassos os estudos epidemiológicos sobre a ocorrência de hemoplasmas em felinos selvagens em todo o mundo. O objetivo deste estudo foi (1) avaliar a ocorrência e a filogenia de hemoplasmas em felinos selvagens cativos em um zoológico do Estado

\footnotetext{
Profs. Drs., União de Ensino do Sudoeste do Paraná, UNISEP, Dois Vizinhos, PR, Brasil. E-mail: clau.mribeiro@hotmail.com; felippe@unisep.edu.br; patriciapaivalima@gmail.com

2 M.e em Química, Departamento de Medicina Veterinária Preventiva, Universidade Estadual de Londrina, UEL, Londrina, PR, Brasil. E-mail: aldair@uel.br

3 Pesquisadora, Núcleo de Ciências Biomédicas, Instituto Adolfo Lutz, IAL, Bauru, SP, Brasil. E-mail: virichini@yahoo.com.br

4 Prof $^{a}$ Dra $^{\text {a }}$ Departamento de Descentralização do Desenvolvimento, Agência Paulista de Tecnologia dos Agronegócios, APTA, Bauru, SP, Brasil. E-mail: silucheis@yahoo.com.br

5 Discente, União de Ensino do Sudoeste do Paraná, UNISEP, Dois Vizinhos, PR, Brasil. E-mail: juhitap@hotmail.com

6 Prof $^{a}$ Dra $^{\text {a }}$, Universidade Federal de Mato Grosso, UFMT, Barra do Garças, MT, Brasil. E-mail: sativet@gmail.com

Prof. Dr., Departamento de Medicina Veterinária Preventiva, UEL, Londrina, PR, Brasil. E-mail: vidotto@uel.br

Author for correspondence
}

Received: Oct. 14, 2016 Approved: Apr. 10, 2017 
do Paraná, Brasil, (2) e verificar a correlação entre as subpopulações destas bactérias e os parâmetros hematológicos e bioquímicos dos animais. A PCR foi utilizada para detecção de hemoplasmas em sangue de três pumas (Puma concolor), uma onça (Panthera onca), um tigre (Panthera tigris) e uma leoa (Panthera leo), seguida de sequenciamento e análise filogenética. Constatou-se que os pumas e a onça foram PCR-positivos para hemoplasma. A análise filogenética das sequências do gene 16S rRNA permitiu identificar genótipos de 'Candidatus Mycoplasma haemominutum' circulando neste zoo. As sequências identificadas apresentaram relações estreitas com sequências de hemoplasmas procedentes de gatos domésticos e de outros felinos selvagens; contudo, os pumas e a onça infectados apresentaramse saudáveis e sem alterações hematológicas ou bioquímicas. Conclui-se que $P$. concolor e $P$. onca são expostos à 'Candidatus Mycoplasma haemominutum' no Paraná, porém sugere-se a realização de pesquisas futuras para avaliar a resistência dos felinos selvagens frente à diferentes subpopulações de hemoplasmas.

Palavras-chave: Caracterização molecular. Hemoplasmas. Panthera onca. PCR. Puma concolor.

In practical applications for the prevention, surveillance and detection of disease, the "One Health" concept has been used, which consists in the joint effort of human medicine, veterinary medicine, and ecology to ensure the health of humans, domestic and wild animals, and the environment (JENKINS et al., 2015). Surveillance of the health of wild felines can therefore contribute to a better understanding of the role of these carnivores in the epidemiology of emerging pathogens that pose a risk to human health and may adversely affect wild animal populations of conservation interest.

Hemoplasmas are pleomorphic bacteria belonging to the family Mycoplasmataceae and are found attached to the epicellular region of erythrocytes (BIONDO et al., 2009). The species Mycoplasma haemofelis, 'Candidatus Mycoplasma haemominutum' and 'Candidatus Mycoplasma turicensis' are etiologic agents of feline hemotropic mycoplasmosis which been observed in cats (Felis catus) with hemolytic anemia (NIBBLETT et al., 2009; WEINGART et al., 2016).

Zoonotic infections by hemoplasmas are considered emergent and an increasing number of cases have been reported, particularly in immunodeficient patients. Septic arthritis caused by M. haemofelis was diagnosed in a woman suffering from hypogammaglobulinemia in the United States (BONILLA et al., 1997). In Brazil, M. haemofelis was detected in an HIV-positive patient co-infected with Bartonella henselae (SANTOS et al., 2008), demonstrating the occurrence of interspecific transmission of this pathogen.

Few investigations have focused on the distribution and prevalence of hemoplasmas in captive or free-living wild feline populations. Nevertheless, hemoplasma infections have been reported in leopard cats (Prionailurus bengalensis euptilura) in Korea (HWANG et al., 2015), european wildcats (Felis silvestris), iberian lynx (Lynx pardinus) and eurasian lynx (Lynx lynx) in Europe, lions (Panthera leo) in Africa, and in neotropical felines in Brazil: jaguarondis (Puma yagouaroundi), ocelots (Leopardus pardalis), margays (Leopardus wiedii), geoffroy's cats (Leopardus geoffroyi), oncillas (Leopardus tigrinus), cougars (Puma concolor) and jaguars (Panthera onca) (WILLI et al., 2007; ANDRÉ et al., 2011).

Previous studies on the genetic diversity of hemoplasmas in wild felines have demonstrated that strains of these bacteria differ in geographical distribution (WILLI et al., 2007; HWANG et al., 2015), but they do not mention whether the subpopulations of hemoplasmas express different virulence phenotypes. However, genetic variations may play an important role in the epidemiology and pathogenesis of feline hemotropic mycoplasmosis.

Given that hemoplasmas can significantly impact the health of wild animals and humans, 
this study aims to: (1) evaluate the occurrence and genetically characterize the hemoplasmas detected in naturally infected captive wild felines, and (2) determine whether there is a correlation between subpopulations of these pathogens and the hematological and biochemical parameters of the felines.

All the procedures used in this study were approved by IBAMA, the Brazilian Institute of Environment and Renewable Natural Resources (Permit No. 53804-1).

The evaluation involved three cougars (Puma concolor), a jaguar (Panthera onca), a lion (Panthera leo) and a tiger (Panthera tigris), males and females ranging in age from 2 to 10 years and living in captivity at the zoo of the Paraná Southwest Education Union, in the state of Paraná, Brazil (25 $\left.45^{\prime} 0^{\prime \prime} \mathrm{S}, 53^{\circ} 3^{\prime} 25^{\prime \prime} \mathrm{W}\right)$. The felines were immobilized for routine clinical exams and the collection of blood samples by cephalic venipuncture. A combination of tiletamine and zolazepam $\left(\right.$ Zoletil $\left.^{\circledR}\right)$ associated with detomidine (Dormium $\mathrm{V}^{\circledR}$ ) was used to chemically restrain the cougars, jaguar and lioness, while a combination of ketamine (Ketamine $\mathrm{S}+{ }^{\circledR}$ ) and detomidine (Dormium $\mathrm{V}^{\circledR}$ ) was used for the tiger. The doses were calculated using interspecific allometric scaling.

Blood cell counts were made of the blood samples collected with EDTA, using a Sysmex ${ }^{\circledR}$ pocH-100iV Diff veterinary hematology analyzer. The samples collected without anticoagulant were centrifuged in a Nova Instruments ${ }^{\circledR}$ N1 1812 lab centrifuge at 2,500 rpm for $5 \mathrm{~min}$ to obtain the serum, in which the total proteins, urea and creatinine concentrations were measured using a semi-automatic biochemical analyzer (Bioplus 2000 ${ }^{\circledR}$ ) and commercial kits (Bioclin ${ }^{\circledR}$, Brazil).

Genomic DNA was extracted from $200 \mu \mathrm{L}$ of blood using a commercial DNeasy ${ }^{\circledR}$ Blood \& Tissue kit (Qiagen, Germany) and was stored at $-20^{\circ} \mathrm{C}$ until PCR was performed. The primers 16S_HAEMOforw ( 5 '-GGCCCATAT TCC TRCGGGAAG-3') and

16S_HAEMOrev

(5'-ACRGGATTACTAGTGATTCCA-3'), which amplify a fragment of the 16S rRNA gene (950 pb), were used for the detection of Mycoplasma spp. (HOELZLE et al., 2011). The PCR reaction was performed in a final volume of $25 \mu \mathrm{L}$ containing 1 $\mu \mathrm{L}$ of genomic DNA, 5 pmol of each primer, 200 $\mu \mathrm{M}$ of dNTP, 1X Platinum PCR buffer, $1.5 \mathrm{mM}$ of $\mathrm{MgCl}_{2}$ and $1.25 \mathrm{U}$ of Platinum ${ }^{\mathrm{TM}}$ Taq DNA Polymerase (Invitrogen ${ }^{\mathrm{TM}}$ ). The following thermal sequences were used: an initial cycle at $95^{\circ} \mathrm{C}$ for $5 \mathrm{~min}$, followed by 35 cycles at $95^{\circ} \mathrm{C}$ for $1 \mathrm{~min}$, annealing at $60^{\circ} \mathrm{C}$ for $45 \mathrm{~s}$, at $68^{\circ} \mathrm{C}$ for $1.5 \mathrm{~min}$, and a final extension at $68^{\circ} \mathrm{C}$ for $5 \mathrm{~min}$.

M. haemofelis DNA detected in a cat treated at the Veterinary Hospital of the State University of Londrina was used as positive control and ultrapure water (Invitrogen ${ }^{\mathrm{TM}}$ ) as negative control. The products of PCR were visualized on $1.5 \%$ agarose gel stained with SYBR $^{\circledR}$ Safe DNA Gel Stain (Invitrogen ${ }^{\mathrm{TM}}$ ).

Amplicons were sequenced with BigDye $^{\circledR}$ Terminator v3.1 Cycle Sequencing Kit (Applied Biosystems ${ }^{\circledR}$ ) and the automated sequencer $\mathrm{ABI}$ 3500 Genetic Analyzer (Applied Biosystems ${ }^{\circledR}$ ). Multiple sequence alignment was carried out using ClustalW, while phylogenetic trees were built using the Maximum Likelihood method by Mega 7 software (KUMAR et al., 2016). Tajima's D test (TAJIMA, 1989) was used to infer deviations from neutrality of the 16S rRNA gene sequences of detected hemoplasmas.

Among the investigated felines, the three cougars and the jaguar were positive for hemoplasmas by the PCR-based determination method. The partial sequence of the 16S rRNA gene of Mycoplasma spp. was analyzed by comparison with sequences deposited in GenBank. Genotypes 1, 2, 3 and 4 presented $>99 \%$ similarity with 'Candidatus M. haemominutum' under accession numbers KM275248.1， KM275257.1， KJ135321.1, KJ135328.1， EU128752.1， FJ004275.1, 
EU839984.1, JN368078.1, DQ825457.1, Twenty-five nucleotide sequences of 'Candidatus DQ825456.1, DQ825455.1, DQ825452.1, M. hamominutum' were evaluated by means of DQ825446.1, DQ825445.1, DQ825443.1, the Tajima D test and presented a negative value DQ825440.1 and DQ825439.1 (Figure 1). All the $(\mathrm{p}<0.05)$, indicating that this population may be animals tested negative for $M$. haemofelis and expanding (Table 1).

'Candidatus Mycoplasma turicensis.'

Figure 1. 16S rRNA tree of 'Candidatus Mycoplasma haemominutum' of Puma concolor and Panthera onca (genotypes 1, 2, 3 and 4), generated through Maximum Likelihood analysis. The tree is drawn to scale, with branch lengths measured in the number of substitutions per site. The analysis involved 26 nucleotide sequences and the final dataset contained a total of 203 positions. The scale bar represents 0.050 different nucleotides among the sequences. The numbers above and below the branches indicate bootstrap values.

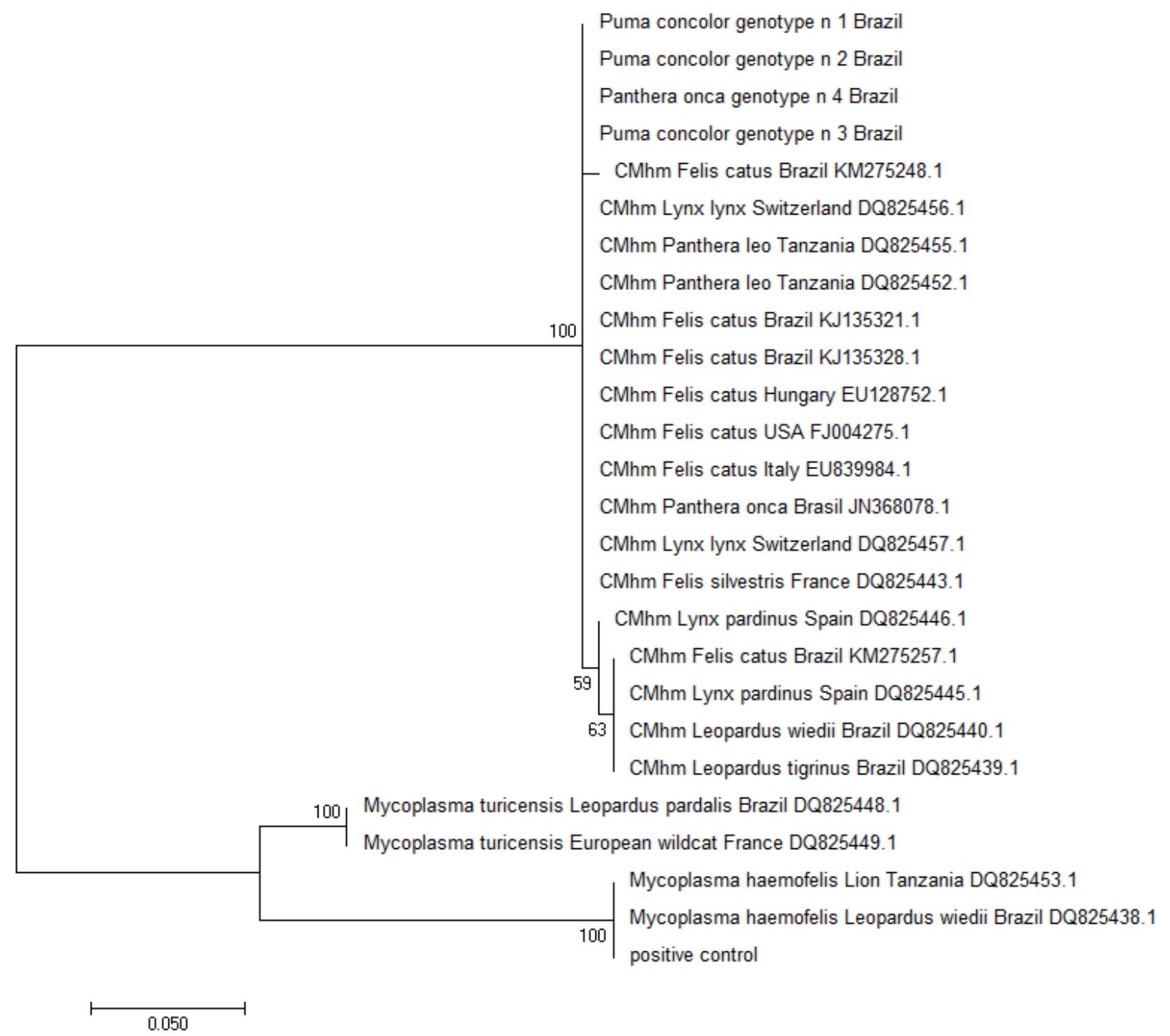


Table 1. Neutrality test of 'Candidatus Mycoplasma haemominutum' detected in captive Puma concolor and Panthera onca in Paraná, Brazil.

\begin{tabular}{ccccc}
\hline Gene loci & $m$ & $S$ & $\pi$ & $D$ \\
\hline 16S rRNA & 25 & 67 & 0.077274 & -0.451499 \\
\hline
\end{tabular}

$m$ : number of sequences; $S$ : number of polymorphic sites; $\pi$ : nucleotide diversity; $D$ : Tajima's D.

The degree of pathogenicity of the genotypes was assessed based on physical examination and determination of the hematological and biochemical parameters of the animals. The felines PCR-positive for 'Candidatus M. haemominutum' appeared healthy in the clinical examination, without hematological or biochemical changes (Table 2). However, high levels of urea were found in the animals, which were attributed to their high protein diet.
The need to investigate the health of wild animals is recognized, since emerging infectious diseases have become increasingly prevalent in these animals. In this study, 'Candidatus M. haemominutum' was detected in $P$. concolor and $P$. onca, which are neotropical felines found in Brazil that are in decline and are classified as vulnerable to extinction by the Chico Mendes Institute for Biodiversity Conservation (BRASIL, 2014).

Table 2. Mean \pm SEM of the hematological and biochemical parameters of Puma concolor and Panthera onca PCRpositive for 'Candidatus Mycoplasma haemominutum'.

\begin{tabular}{lcccc}
\hline Parameters & Puma concolor & Reference values & Panthera onca & Reference values \\
\hline Erythrocytes $\left(10^{6} \mu \mathrm{L}^{-1}\right)$ & $9.45 \pm 0.26$ & $7.41 \pm 0.77$ & $8.4 \pm 0.00$ & $6.99 \pm 1.02$ \\
Hemoglobin $\left(\mathrm{g} \mathrm{dL}^{-1}\right)$ & $15.13 \pm 0.18$ & $11.77 \pm 1.36$ & $11.5 \pm 0.00$ & $10.73 \pm 1.56$ \\
PCV $(\%)$ & $43.10 \pm 1.20$ & $34.75 \pm 4.15$ & $32.7 \pm 0.00$ & $32.95 \pm 4.9$ \\
$\mathrm{MCV}(\mathrm{fL})$ & $45.56 \pm 1.28$ & $46.9 \pm 3.18$ & $39 \pm 0.00$ & $47.2 \pm 3.3$ \\
MCHC $\left(\mathrm{g} \mathrm{dL}^{-1}\right)$ & $35.16 \pm 0.48$ & $33.95 \pm 1.78$ & $35.6 \pm 0.00$ & $32.61 \pm 1.33$ \\
Leukocytes $\left(10^{3} \mu \mathrm{L}^{-1}\right)$ & $10.53 \pm 0.85$ & $8.35 \pm 2.07$ & $13.40 \pm 0.00$ & $10.86 \pm 2.54$ \\
Neutrophils $\left(10^{3} \mu \mathrm{L}^{-1}\right)$ & $6.50 \pm 0.50$ & $7.23 \pm 1.71$ & $9.38 \pm 0.00$ & $7.27 \pm 1.31$ \\
Platelets $\left(10^{3} \mu \mathrm{L}^{-1}\right)$ & $330.33 \pm 27.48$ & $292 \pm 116$ & $390 \pm 0.00$ & $281 \pm 115$ \\
Creatinine $\left(\mathrm{mg} \mathrm{dL}^{-1}\right)$ & $1.36 \pm 0.6$ & $2.4 \pm 0.7$ & $1.4 \pm 0.00$ & $1.9 \pm 0.6$ \\
Urea $(\mathrm{mg} \mathrm{dL}-1)$ & $44.66 \pm 3.28$ & $29 \pm 9$ & $61 \pm 0.00$ & $25 \pm 10$ \\
Total proteins $\left(\mathrm{g} \mathrm{dL}^{-1}\right)$ & $6.16 \pm 0.23$ & $7.3 \pm 0.6$ & $6.1 \pm 0.00$ & $7.4 \pm 0.7$ \\
\hline
\end{tabular}

PCV: packed cell volume; MCV: mean corpuscular volume; MCHC: mean corpuscular hemoglobin concentration. Reference values: Adania et al. (2014).

'Candidatus M. haemominutum' is the most prevalent species in cats in South America, North America and Europe (KAMRANI et al., 2008; SANTIS et al., 2014; DUARTE et al., 2015). However, few studies have focused on determining the prevalence of 'Candidatus $\mathrm{M}$. haemominutum' in neotropical felines. In Brazil, Willi et al. (2007) and André et al. (2011) used molecular tools and detected this pathogen in P. onca, P. concolor, P. yagouaroundi, L. pardalis, $L$. tigrinus and $L$. geoffroyi from the Federal District and the states of São Paulo and Mato Grosso. 
The phylogenetic analysis based on the 16S rRNA gene of 'Candidatus M. haemominutum' indicated that the genotypes 1, 2, 3 and 4 identified in $P$. concolor and $P$. onca were highly similar and were included in the same subclade (Figure 1). The negative result of Tajima's D test may indicate that these hemoplasmas are undergoing positive selection, resulting in a lower level of nucleotide diversity $(\pi)$ and an excess of low frequency variants (Table 1).

The sequences obtained from 'Candidatus M. haemominutum' showed strong evolutionary homology with sequences derived from eurasian lynxes in Switzerland, lions in Tanzania, european wildcats in France, jaguars in Brazil and domestic cats in various countries around the world, such as Brazil, United States, Hungary and Italy (Figure 1), indicating that genotypes 1,2,3 and 4 of 'Candidatus M. haemominutum' are able to infect both wild and domestic felines (WILLI et al., 2007; HORNOK et al., 2008; ANDRÉ et al., 2011; SANTIS et al., 2014).

However, the strains detected in L. pardinus in Spain (DQ825445.1 and DQ825446.1), L. tigrinus (DQ825439.1), L. wiedii (DQ825440.1) and cats (KM275257.1) in Brazil were included in different subclades, indicating a similarity among these sequences, despite the low bootstrap values observed in the phylogenetic tree.

Among the three hemoplasma species that infect felines, 'Candidatus M. haemominutum' is considered the least pathogenic and clinical symptoms of the infection have been reported in co-infections with other hemoplasma species, retroviruses or hemoparasites (WILLI et al., 2007; NIBBLETT et al., 2009). However, hemolytic anemia has been observed in cats infected with 'Candidatus M. haemominutum', without the presence of concomitant diseases or infections (WEINGART et al., 2016). In Hungary, Hornok et al. (2008) observed hemolytic anemia, elevated white blood cell count with neutrophilia, jaundice, and hemoglobinuria in cats infected with the 'Candidatus M. haemominutum' strain (EU128752.1); all the felines were negative for other hemoplasma and retrovirus species.

With regard to wild felines, the few studies that have detected 'Candidatus M. haemominutum' infection reported only that the sampled felines were asymptomatic and showed no changes in packed cell volume (PCV) (WILLI et al., 2007; ANDRÉ et al., 2011; HWANG et al., 2015). Willi et al. (2007) also noted that iberian lynxes PCR-positive for 'Candidatus M. haemominutum' become free of the infection 1 to 2 years after its detection, indicating that wild felines may be more resistant to hemoplasma infections than domestic cats.

It has also been suggested that the absence of obvious clinical signs in wild felines infected with hemoplasmas is because blood sampling was done during the chronic phase rather than the acute phase of the infection (WILLI et al., 2007; ANDRÉ et al., 2011).

This study sought to determine whether there is a correlation between the genotypes of 'Candidatus M. haemominutum' and the hematological and biochemical values of $P$. concolor and $P$. onca. The PCR-positive felines were asymptomatic, showing no changes in blood count or in total protein and creatine levels (Table 2), and had no history of disease. These animals are observed and monitored daily, but have never presented symptoms that would characterize the acute phase of hemoplasma infection. Also worth noting is that the felines presented no virus or hemoparasite co-infections, since they were PCR-negative for herpes I virus, felineimmunodeficiency virus, feline leukemia virus, feline parvovirus, Babesia canis vogeli, Ehrlichia canis, Anaplasma platys, Leishmania infantum and Trypanosoma cruzi (data not shown). The absence of clinical or hematological and biochemical changes may indicate the low pathogenicity of these genotypes or the felines' resistance to infection by 'Candidatus M. haemominutum,' even in stressful 
conditions such as captivity.

In conclusion, $P$. concolor and $P$. onca are neotropical felines exposed to infection by 'Candidatus M. haemominutum' in Paraná. These results expand the body of knowledge about the occurrence of 'Candidatus M. haemominutum' in captive wild felines in Brazil and provide information about the epidemiology of feline hemotropic mycoplasmosis. However, the limited number of reports of wild felines positive for hemoplasmas suggests the need for continuous surveillance of infections by this pathogen in order to determine the genetic diversity and degree of virulence of hemoplasma subpopulations, as well as the resistance of felines during infection.

\section{References}

ADANIA, C. H.; SILVA, J. C. R.; FELIPPE, P. A. N. Carnivora-Felidae (Onça, Suçuarana, Jaguatirica e Gatodo-mato). In: CUBAS, Z. S.; SILVA, J. C. R.; CATÃODIAS, J. L. Tratado de animais selvagens. São Paulo: Roca, 2014. p. 779-818.

ANDRÉ, M. R.; ADANIA, C. H.; ALLEGRETTI, S. M.; MACHADO, R. Z. Hemoplasmas in wild canids and felids in Brazil. Journal of Zoo and Wildlife Medicine, Lawrence, v. 42, n. 2, p. 342-347, 2011.

BIONDO, A. W.; SANTOS, A. P. dos; GUIMARÃES, A. M.; VIEIRA, R. F.; VIDOTTO, O.; MACIEIRA, D. B.; ALMOSNY, N. R.; MOLENTO, M. B.; TIMENETSKY, J.; MORAIS, H. A. de; GONZÁLEZ, F. H.; MESSICK, J. B. A review of the occurrence of hemoplasmas (hemotrophic mycoplasmas) in Brazil. Revista Brasileira de Parasitologia Veterinária, São Paulo, v. 18, n. 3, p. 1-7, 2009.

BONILLA, H. F.; CHENOWETH, C. E.; TULLY, J. G.; BLYTHE, L. K.; ROBERTSON, J. A.; OGNENOVSKI, V. M.; KAUFFMAN, C. A. Mycoplasma felis septic arthritis in a patient with hypogammaglobulinemia. Clinical Infectious Diseases, Chicago, v. 24, n. 2, p. 222225, 1997.

BRASIL. Portaria do Ministério do Meio Ambiente, $\mathrm{n}^{\circ}$ 444. Diário Oficial [da] União, 2014. Disponível em: $<\mathrm{http}: / /$ www.icmbio.gov.br/portal/>. Acesso em: 23 jul. 2016.

DUARTE, A.; MARQUES, V.; CORREIA, J. H.; NETO, I.; BRÁZ, B. S.; RODRIGUES, C.; MARTINS,
T.; ROSADO, R.; FERREIRA, J. P.; SANTOS-REIS, M.; TAVARES, L. Molecular detection of haemotropic Mycoplasma species in urban and rural cats from Portugal. Journal of Feline Medicine and Surgery, London, v. 17, n. 6, p. 516-522, 2015.

HOELZLE, K.; WINKLER, M.; KRAMER, M. M.; WITTENBRINK, M. M.; DIECKMANN, S. M.; HOELZLE, L. E. Detection of Candidatus Mycoplasma haemobos in cattle with anaemia. The Veterinary Journal, London, v. 187, n. 3, p. 408-410, 2011.

HORNOK, S.; MELI, M. L.; GÖNCZI, E.; IGNITS, E.; WILLI, B.; LUTZ, H.; HOFMANN-LEHMANN, R. First molecular identification of 'Candidatus mycoplasma haemominutum' from a cat with fatal haemolytic anaemia in Hungary. Acta Veterinaria Hungarica, Budapest, v. 56, n. 4, p. 441-450, 2008.

HWANG, J.; OH, D. H.; LEE, H.; CHUN, M. S. Anaplasma sp. and hemoplasma infection in leopard cats (Prionailurus bengalensis euptilurus) from Korea. Journal of Veterinary Science, Seoul, v. 16, n. 3, p. 385388, 2015.

JENKINS, E. J.; SIMON, A.; BACHAND, N.; STEPHEN, C. Wildlife parasites in a one health world. Trends in Parasitology, Oxford, v. 31, n. 5, p. 174-180, 2015.

KAMRANI, A.; PARREIRA, V. R.; GREENWOOD, J.; PRESCOTT, J. F. The prevalence of Bartonella, hemoplasma and Rickettsia felis infections in domestic cats and in cat fleas in Ontario. Journal of Veterinary Medicine and Research, San Diego, v. 72, n. 5, p. 411419, 2008.

KUMAR. S.; STECHER, G.; TAMURA, K. MEGA7: Molecular evolutionary genetics analysis version 7.0 for bigger datasets. Molecular Biology and Evolution, Chicago, v. 33, n. 7, p. 1870-1874, 2016.

NIBBLETT, B. M.; SNEAD, E. C.; WALDNER, C.; TAYLOR, S. M.; JACKSON, M. L.; KNORR, L. M. Anemia in cats with hemotropic mycoplasma infection: retrospective evaluation of 23 cases (1996-2005). The Canadian Veterinary Journal, Guelph, v. 50, n. 11, p. 1181-1185, 2009.

SANTIS, A. C.; HERRERA, H. M.; SOUSA, K. C.; GONÇALVES, L. R.; DENARDI, N. C.; DOMINGOS, I. H.; CAMPOS, J. B.; MACHADO, R. Z.; ANDRÉ, M. R. Molecular detection of hemotrophic mycoplasmas among domiciled and free-roaming cats in Campo Grande, state of Mato Grosso do Sul, Brazil. Revista Brasileira de Parasitologia Veterinária, São Paulo, v. 23, n. 2, p. 231-236, 2014.

SANTOS, A. P.; SANTOS, R. P.; BIONDO, A. W.; 
DORA, J. M.; GOLDANI, L. Z.; OLIVEIRA, S. T. haemoplasma species in 22 cats with anaemia. Journal de; SÁ GUIMARÃES, A. M. de; TIMENETSKY, J.; of Feline Medicine and Surgery, London, v. 18, n. 2, p. MORAIS, H. A. de; GONZÁLEZ, F. H.; MESSICK, J. B. Hemoplasma infection in HIV-positive patient, Brazil. Emerging Infectious Diseases, Atlanta, v. 14, n. 12, p. 1922-1924, 2008.

TAJIMA, F. Statistical method for testing the neutral mutation hypothesis by DNA polymorphism. Genetics, Austin, v. 123, n. 3, p. 585-595, 1989.

WEINGART, C.; TASKER, S.; KOHN, B. Infection with 129-136, 2016.

WILLI, B.; FILONI, C.; CATÃO-DIAS, J. L.; CATTORI, V.; MELI, M. L.; VARGAS, A.; MARTÍNEZ, F.; ROELKE, M. E.; RYSER-DEGIORGIS, M. P.; LEUTENEGGER, C. M.; LUTZ, H.; HOFMANNLEHMANN, R. Worldwide occurrence of feline hemoplasma infections in wild felid species. Journal of Clinical Microbiology, Washington, v. 45, n. 4, p. 11591166, 2007. 